\author{
May Britt Postholm
}

Janne Madsen

\title{
The Researcher's Role: An Ethical Dimension
}

\section{Summary}

Different paradigms or perspectives function as the point of departure and framework for research. In this article ethical issues in the positivist and constructivist paradigms are presented. The article points out that more or less the same ethical codes are used in these paradigms, but with some nuanced interpretations. CHAT (cultural historical activity theory) is presented as a third paradigm. While conducting research, one intention within this paradigm is to change and improve practice. This means that the researcher and the research participants during the research process together set the goals for the work and try to change practice en route to these goals. The relation between the researcher and the research participants is different than in the other two presented paradigms. This means that research in the CHAT paradigm also needs to be guided by different ethical codes. The purpose of this article is to show how some of the traditional ethical codes which direct research both in the positivist and constructivist paradigm change and are also inadequate in the CHAT paradigm. The article presents and discusses ethical codes that challenge the researchers' communicative, social and knowledge competence.

\section{The Researcher's Role:}

\section{An Ethical Dimension}

Different paradigms or perspectives on the world function as the point of departure and framework for research. Two of these have been called the positivist and the constructive paradigms. The researcher's role and the challenges he or she meets depend on which of these paradigms the research is conducted within. In the positivist tradition researchers have focused on capturing what has existed "out there" in the world and representing it objectively. Within the constructivist tradition researchers interpret the data and construct their beliefs within the framework of a social, historical and cultural context. We claim that research based on cultural historical activity theory (CHAT) represents a third paradigm. In this paradigm the researcher's aim is to understand the participants' actions, and additionally to improve practice together with the research participants while research is being undertaken. This means that there can be a close relation between the researcher and the research participants in this paradigm. As you will see, this relation is somewhat different in the two other above-mentioned paradigms. The purpose of this article is to show how traditional ethical principles change when all parties in the research process have a close relation to each other, and, furthermore, to show how this situation challenges 
the researcher. Our focus is on research in the CHAT tradition.

We will first describe the traditional ethical codes used in the positivist and constructivist paradigms as a basis for how ethical codes can be understood, discussed and developed. In the text our reflections are based on educational research. ${ }^{1}$ With the various perspectives, views and aims that are found in these paradigms, it is natural to assume that various ethical codes will be relevant in research conducted within them. However, the ethical codes that were used in the positivist paradigm are still in use in the constructivist paradigm. Glesne (1999) uses the same ethical codes as in the positivist paradigm when she discusses ethics in traditional qualitative research, and Guba and Lincoln (1989) state, for instance, that such issues as privacy and confidentiality are not pointless or outmoded in constructivist inquiry. "Quite the opposite," as they say (p. 133). Nonetheless, researchers in the various paradigms give, as we will see, the various codes some nuanced interpretations. In the following text we present ethical codes that are used in both these paradigms.

\section{Ethical Codes in the Positivist and Constructivist Paradigms}

The intention of research in the positivist paradigm was to contribute to human welfare. This noble aim notwithstanding, experiments like the ones conducted in Nazi concentration camps, and the development of the atomic bomb have undermined this image of science (Diener \& Crandall 1978). Moreover, some

1 The data material in this article is from Madsen's doctoral study. This work is in progress at a small school in the northern part of Norway. The school has nine teachers and about 30 students. The doctoral work is planned for completion in 2008, ending in a dissertation. In this work, a school development project, Madsen is an active participant in the project management group. The study is being conducted in the cultural historical activity theory paradigm. medical research in the United States resulted in physical harm to subjects. LSD was tested on unsuspecting people, and patients in mental hospitals were infected with syphilis to study the life-course development of this disease (Guba and Lincoln 1989). Due to this type of research it became crucial to develop rules or guidelines that could protect people from both physical and psychological harm. This means that the need for ethical guidelines has grown out of medical and others types of intrusive research (Glesne 1999).

When data are collected or participants are drawn into research without their knowledge, the term deception has been used to describe the situation (Glesne 1999). In the positivist paradigm deception is sometimes considered justifiable when the aim is to control variables to find out what is really "out there". According to Guba and Lincoln (1989), deception is not only unwarranted in the constructivist paradigm, but it is even in conflict with its aims. Social reality is not objectively "out there", but it exists in several mental and social constructions created in social interaction. We can find as many realities as there are persons in a situation (Guba \& Lincoln 1989). However, historicity and culture will nonetheless be factors that diminish subjective relativism, implicating that everything can not mean everything. The aim of research in this paradigm is to reach a joint construction of reality that emerges as a result of hermeneutic dialectic processes (Postholm 2003). As opposed to research conducted in the positivist paradigm where the observer is separated from the observed, the researcher in the constructivist paradigm interacts with the participants to understand their social constructions, and furthermore represents this understanding (Glesne 1999). Thus the reported text represents a joint or collaborative construction (Guba \& Lincoln 1989). While the axiological stance of research in the positivist paradigm is value-free, research in the constructivist paradigm is value-bound. Therefore 
researchers in the constructivist paradigm also are critical or try to become conscious of their own subjectivity (Lincoln \& Guba 1985).

The purpose of inquiry in the constructivist paradigm is to uncover realities as they are constructed by persons in them. To deceive the research participants by not telling them about your focus and aim means that the researcher could obtain information that is irrelevant (Guba \& Lincoln 1989). However, such an approach could also be relevant to some degree in inquiry conducted in the constructivist paradigm. The aim for research conducted in this paradigm can be to find out how teachers communicate with pupils in a class. If researchers tell the teacher what they are focusing on, the teacher's communication pattern will probably change. In another research project the aim could be to find out how some pupils are bullying others in the class. If researchers inform about their focus, the pupils' behaviour will also most likely change. Thus the researcher may also choose to withhold some information in the constructivist paradigm, so she can accomplish the aims of the research project.

In experiments when people are put at risk, they may be harmed (Guba \& Lincoln 1989). In the constructivist paradigm situations can also arise that may harm research participants psychologically. Rubin and Rubin (1995) state that it is the researchers' duty to distinguish between private and confidential information and information that can give an answer to the research question. According to them, the researcher can place the participants in a psychologically difficult situation by asking questions. Thus it is the researcher's responsibility to protect the participants' privacy by retaining information that can put the participants at risk. This also means that some information needs to be kept confidential. According to Fontana and Frey (1998, 1994/2000), working from the constructivist perspective, responsibility has to be directed first at the research participants, second the research project and third and last the researcher him or herself.

Intrusive research has, as mentioned above, led to an emphasis on a number of ethical concerns. In addition to deception, avoidance of harm, privacy and confidentiality, researchers have pointed to informed consent, exploitation, anonymity and reciprocity as important issues when dealing with ethical challenges (Glesne 1999). Informed consent means that research participants know what they are being invited to take part in before the research starts, and that they answer yes to this invitation (Angrosino \& Mays de Pérez 2000, Fetterman 1998, Fontana \& Frey 1998, 1994/2000, Hammerley \& Atkinson 1995, Merriam 1998, Moustakas 1994, Patton 2002, Punch 1994, Stake 1995). The participants are guaranteed the right to know the purpose of the research and what role they are going to have in the research process. They are also informed that they have the right to withdraw from the research at any time, also taking the data with them. Researchers must also inform the participants that anonymity is ensured by using pseudonyms (Fetterman 1998, Patton 2002, Rubin \& Rubin 1995). Bogdan and Biklen (1992) state that participants also have to be given thorough information on how the results will be reported. Nevertheless, informed consent shows that there is an asymmetrical relationship between the researcher and the research participants. The researcher "tells", and the participants are "told" (Glesne 1999). There will always be a third party in classrooms. We will return to this when we discuss ethical principles in the CHAT paradigm.

The distance between the researcher and the research participants that is upheld through such consent requirements maintains, among other things, the principle of objectivity and value-freedom as in the positivist paradigm. Informed consent is also often formalized in a contract. Close cooperation between the participants will however, in Bogdan and Biklen's 
(1992) opinion, make such a contract superfluous. This does not mean that the participants do not need to be fully informed before the research begins. Nonetheless, when research becomes collaborative, the relation between the researcher and the research participants may exceed the demands of informed consent (Soltis 1990). Pateman (1989) describes such a relation by saying that promises are one of the basic ways in which consenting human beings "freely create their own social relationship" (p. 71).

In a qualitative study conducted in the constructivist paradigm, it can also be difficult for researchers to give the participants all the information beforehand because new knowledge and insight gained during the research project can change the plans. This means that the participants have to be informed before the research starts that the project could turn in a slightly new direction than what has been the plan. This must therefore be included in the total information the participants are given or consent to. Lincoln (1995) calls the criteria that can judge if such qualitative inquiries are ethical or not emerging relational criteria. This means that the ethical criteria are developed and even created during the research process in the close relationship between the researchers and the research participants. Researchers must solve ethical dilemmas in connection with the situation they are a part of. Thus ethical guidelines in qualitative research conducted in the constructivist paradigm are context-bound.

During a research project conducted in the constructivist paradigm the researcher usually realizes that the research project has gathered and required a lot of information and effort from the participants. It is therefore an ethically proper responsibility to give the participants something in return (Fetterman 1998), and they should be told in advance what they will get in return. However, the researcher should not promise more than he or she can give. The par- ticipants can, for instance, be given a copy of the research text, or the researcher may promise to return to the people in the research setting to tell them the whole story constructed in that setting. In this way the researcher can alleviate any feelings of exploitation, and the research participants will probably not feel like they have been exploited.

In the constructivist paradigm co-construction of realities and the close relationship between the researcher and the participants lay the foundation for reciprocity between the parties. Reciprocity is defined as "the exchange of favors and commitments, the building of a sense of mutual identification and feeling of community" (Glazer 1982, p. 50). In some research this reciprocity can be, as mentioned above, to reward the participants for the time they have invested (Glesne 1999). The time the researchers are spending with participants is invaluable to them and their research project. Glesne (1999) wonders if the participants feel the same in connection with the researchers' practice. Her own answer to this is; "probably not". Glesne's conclusion is that equivalency and balanced reciprocity are difficult to achieve in traditional qualitative research. Reciprocity means that the participants are given something in return for the information they have provided. One privilege could be royalties or they may be presented as co-authors of publications (Creswell 1998). If the participants want to be co-authors, using their real name, the principle of anonymity has to be reconsidered. However, it is the researcher's ethical responsibility to ensure that no one is put in a bad light and furthermore to protect their privacy. If, for instance, some students in a research text that represents a practice in a classroom have behavioural problems or learning difficulties, they can be recognized when the teacher is presented as a co-author with his or her real name. Anonymity, confidentiality together with reciprocity therefore have to be considered together to serve all the 
participants the best way in the research process in the constructivist paradigm.

A paradigm includes, as we have seen, both a systematic set of beliefs, a theory, and the accompanying methods. In the following we present the CHAT paradigm with its ontological, epistemological and axiological perspectives and the methods used in this paradigm.

\section{The CHAT Paradigm}

As in the constructivist paradigm, the ontological perspective in the CHAT paradigm is that realities are multiple and constructed, but historicity and culture will be factors that will diminish subjective relativism in this paradigm as well (Postholm 2003). Realities are constructed in the two-way interaction between the persons and the environment they live and act in, and any development that starts in an individual begins in a social, cultural and historical context (Wertsch 1981). At the same time persons influence the sociocultural context they are a part of. In our opinion such a view has consequences for the epistemological stance, that is, how to perceive the relationship between the researcher and the research participants in a classroom. Once researchers enter a classroom they become part of the surroundings for the actions playing out there.

In the constructivist paradigm the researcher interacts with the research participants to understand their social constructions and represent this understanding in a text (Glesne 1999). In the CHAT paradigm the researcher not only interacts to understand and represent this understanding in a text, he or she also aims to create new ways of carrying out actions together with the local participants during the research project (Engeström 1999). This means that the researcher in the CHAT paradigm adopts an active role together with the participants in the research to attempt to change the practice. Such a manner of undertaking research constitutes methodological viewpoints that function as guidelines for qualitative research on processes. The knowledge that is created and the development that occurs in practice emerge from this interaction between researchers and participants during the research activity. The axiological viewpoint in CHAT is that research is value-bound. In the CHAT paradigm researchers are not just critical and conscious of their own subjectivity as in the constructivist paradigm, they also reveal their subjectivity in ongoing interactions with the research participants when discussing objectives and goals. Thus it is all the participants' values and attitudes that drive the developmental process.

The school curriculum and subject syllabuses form the frames for researchers' and teachers' creative thinking processes in schools. Changing a practice may be initiated and occur in relation to the common notions held by both researchers and participants when it comes to how a changed practice should be. This common notion of a preferred practice is thus a tertiary artefact and also a goal to work toward in the work process. A notion of a changed practice will also provide directions for plans made before the teaching starts. Wardekker (2000) states that the quality of research work should be expressed in relation to whether this work has caused positive changes with regard to the aims set by the researchers and teachers. In our view this gives the researcher co-responsibility for both the research results and the changes of practice, and this implies an extension of the researcher's role that has been prevalent in the constructivist paradigm. The researcher is not merely a collaboration partner collecting data in the classroom to be presented and analyzed in a text that may be read. That the text is read is no guarantee that changes occur in practice. The researcher in the CHAT paradigm is co-responsible for changing processes throughout the research work and for creating a research text. 


\section{Ethical Codes in the CHAT Paradigm}

Research that aims to influence the research field as little as possible during the research process has been carried out both within the positivist and constructivist paradigms. One might ask whether this is the most appropriate way of carrying out research processes. Qualitative researchers who enter various research fields have more or less studied theory illuminating the field in advance. Classroom researchers often also have classroom experiences as teachers (Nilssen, Wangsmo-Cappelen \& Gudmundsdottir 1996, Reinertsen, Nordtømme, Eidsvik, Weideman \& Gudmundsdottir 1996, Moen \& Gudmundsdottir 1997, Postholm, Granum \& Gudmundsdottir 1999, Madsen, Svendsen \& Gudmundsdottir 2000, Pettersson, "Tina”, Flem \& Gudmundsdottir 2000). Is it then ethically correct that researchers should not offer the research field their knowledge and experiences and thus assistance and guidance during the research process itself? If researchers basically feel that they can contribute something to the development of the practice field, and the practitioners find the researchers' contribution to be useful, the answer to this question must be an unequivocal no. The following statement also confirms this. A headmaster said to a researcher he and the teachers had invited to their school: "We invited you to come because you know something about our way of working. At the same time you are an outsider and probably see things slightly differently and from another angle than we do" (Madsen in progress). Thus the researcher can represent a supplementary view that can contribute to the development of practice. The researcher can both develop a text as a thinking tool and, as noted, contribute to change during the research process. However, this requires the various parties to agree in advance on objectives for the practice and the progress of the research process. This also coincides with Soltis' (1990) view: the researcher should be ethical both "in the purpose as well as in the process of doing research" (p. 255).

There may be a number of persons or official bodies interested in undertaking research on practices in the classroom. These may be government ministries hiring researchers, or headmasters and teachers who want classroom processes to be examined through the eyes of a researcher. Hence the research question may be the researcher's or the teachers', or they may agree on a common research question. Teachers may, for example, want an external researcher to study various activities and analyze and assess them, and furthermore to discuss his or her reflections with them. In continuous dialogues with the teachers based on the observed actions in practice, the researcher may contribute to development during the research process itself. In this way teachers may receive input and assistance to change their practice while the research is taking place, and also receive feedback on or discuss with the researchers how the changed practice functions compared to goals or objectives decided for the practice. In this process actions that are taken for granted and old forms of actions can be questioned. In both cases, whether it is the researcher or the teacher who initiates the research activities, questions must be raised as to the purpose and aim of the research. The roles of the researcher and the teacher during this activity must be resolved and ethical concerns must be addressed.

In the CHAT paradigm researchers and teachers work on the same project and towards the same end, that is to improve practice. Informed consent as a formal contract between these to parties would be even more superfluous in this paradigm than in the constructivist paradigm. As we have already stated, the teachers could be the ones to invite researchers into their classroom. In such a situation the teachers would initially be the ones to inform about the purpose of the invitation and their thoughts on the teaching and learning practice 
in their classroom. In such a situation both parties together can "create their own relationship" (Pateman 1989, p. 71), not based on prescribed ethical codes, but on the situation and what it demands of them. Even if the communication between researchers and the research participants is open all the way right from the beginning, many of the ethical dilemmas will arise out of specific instances in a study. This means that many of the ethical questions are context-bound. Thus the teachers have to describe their problem or aim, and the researchers their competence that can help the teachers solve their problem or reach their aim. Together they must plan how they would like to try to solve this problem and satisfy the aim for the teaching process. In this way research and teaching would merge into a common process that hopefully enriches both researchers and teachers. Teachers can learn about research processes and researchers about teaching at the same time as they can learn and develop in their own field.

However, in classroom research there is always a third party with regard to ethical issues, the pupils and their parents. ${ }^{2}$ If the teachers and researcher are researching the teaching and learning processes, the pupils and their parents have to be asked for their permission and give their consent. Thus researchers and teachers together can write down how they have planned to carry out the research process to improve practice. The information to the parents and the pupils should also inform them that the plans could change and move in another direction than intended because the best made plans sometimes turn out to be dysfunctional, or the development in the classroom could take another direction than assumed. In this way informed consent as a

2 The school management can also be viewed as an important party next to teachers and researchers. However, in this text the focus is on the pupils and their parents. contract between teachers and researchers will be redundant, but to accomplish their project an informed consent from the third party is necessary.

During the teaching and learning processes in the classroom, researchers and teachers will meet in continuous dialogues both during and around teaching. As the practice moves from carrying out innovations towards internalization, as in the expansive circle (Engeström 1999), dialogues become part of the planning and implementation processes, as when the teachers and researcher talk together about the observations and critical reflections they make on the basis of the activity carried out. These relational discursive situations require that the researcher is an active listener and a supportive interlocutor. Thus researchers must have both communicative and social competence in cooperation with teachers improving practice.

Not only do the participants or teachers need to feel comfortable, it is also necessary that the researchers show a professional competence in the teaching and learning processes, and that they are honest about and willing to share this competence with the participants, the teachers. Such a situation challenges the researchers to speak openly, which in turn creates a situation characterized by trust and mutuality. In such a context teachers will perceive that both parties can approach topics and practices with some common understanding or intersubjectivity (Wertsch 1984, Rommetveit 1979), and they can experience that the talk and discussions between them and the researchers are useful for their teaching practice.

Researchers have various views on whether researchers should know the research field or not. Creswell (1998) and Glesne and Peshkin (1992) are sceptical to research that is conducted by researchers in their own institution. According to them much knowledge about the research field can blind researchers during the data collecting processes. Miles and Huberman (1994) claim that a qualitative researcher 
as an observer and the primary instrument in research should have some knowledge about the phenomena and the setting that are being studied. Kvale (1996) also states that researchers at the outset need some expertise both in connection with the studied theme and in human cooperation. In the same vein, Hammersley and Atkinson (1995) say that it is necessary for ethnographers to know the culture of a group if researchers are to be able to give trustworthy explanations of human actions in the group. Discussions concerning whether it is useful that researchers should know about the research field or not, belongs to research conducted in the constructivist paradigm. In the CHAT paradigm, as we have seen, it is a necessity that researchers have knowledge about the field in which they are going to conduct research and develop. Thus such discussions will be an anachronism in research conducted in the CHAT paradigm.

A dialogue between the teachers at the school taking part in Madsen's study shows that they appreciate the researcher's knowledge about the research field. The dialogue rendered below is from a teachers' meeting at the school. The topic of the dialogue is the school developmental project. The atmosphere is good, and the interlocutors are very willing to talk. The teachers say:

Teacher 1: I'm so glad we could have you as an advisor (to Madsen). It's better to have an outsider.

Teacher 2: Yes, but it couldn't just be anyone from outside.

Teacher 1: No, there are many researchers who know a lot but who talk in a way that we can't understand. You talk clearly and precisely, and you say what you mean (saying this to Madsen).

Teacher 2: I'm glad we have an advisor who knows and understands our practice, and at the same time can help us to understand more.

Teacher 3: You (to Madsen) can also push us more, because you are from the "outside". We need someone to push us, and you have tried to help us work things out. You have said clearly what you mean, and that's important.

Teacher 2: You question things we don't even think of. Sometimes you also force us to bring topics out into the open; topics that we even don't like to talk about (to Madsen).

The teachers in this dialogue state clearly that they are satisfied with a person who knows what their work is like and therefore can give them valuable insight and help. As we see, they also appreciate that Madsen is honest and willing to share her competence and that she speaks clearly.

During the conversations between researchers and participants various topics and issues can be brought out into the open, but it can be a challenge for researchers to distinguish between information that can advance the practice and information that belongs to the private sphere. Normally, researchers will not have any therapeutic competence, and should therefore avoid issues and questions that require such a capability. However, researchers can advise potential teachers to consult professional services if they should find that someone is in need of such a help. In dialogues with groups of teachers it is therefore a challenge for researchers to protect each and every teacher's privacy during the conversation, and furthermore to be sensitive to what information could put the teachers at risk in a research report.

Madsen has experienced this type of challenge in her research. She has undertaken a close-up study of the involved teachers during the school development project. This has included recording them while they are teaching, and using a mini-disc to record dialogues during team meetings and interviews with individual teachers. It is especially during the individual, semi-structured interviews that there is room for unexpected utterances. The teachers have worked at the same school 
for many years, they know each other well and respect each other, although they perceive themselves as distinct personalities. The teachers have opinions about themselves and how they function in the community. The individual interviews, on the other hand, reveal that the teachers have quite different opinions about themselves and the others than their colleagues have. It became clear to Madsen that each teacher's colleagues saw motives in what they did that they probably would have denied having if they had been told what the others thought. Madsen found this to be an ethical dilemma she had to deal with. She had to be sensitive as to how much of this information she could make public and how much she should withhold. She decided to make information public that she felt would advance the project. In her opinion it is obvious that some information can hinder cooperation between teachers, and that some information should be kept confidential and withheld from the other research participants. Researchers must therefore reflect on and also discuss with the participants when it is convenient to keep information confidential. Thus confidentiality and avoidance of harm can also be an issue for research conducted in the CHAT paradigm.

Deception and exploitation will, on the other hand, be non-issues in research conducted within this paradigm when researchers and research participants cooperate. Deception can be seen as covert observation. In research conducted in the CHAT paradigm such an observational practice is unthinkable. Researchers and research participants are working and talking together in their attempt to reach goals which both parties have established in advance. Moreover, this common activity means that researchers are active participants in the developing process, not more or less active observers collecting data. Thus the researchers will not feel they are exploiting the participants, and the participants will not feel they are being exploited. On the other hand, reciprocity or even mutuality will be prevalent in such collaborating research processes.

In Madsen's research project the school with its participants and the researcher have agreed on various issues both orally and in writing. In this way they create their own relationship, to use Pateman's (1989) words. In such agreements the utility value for both parties, the school and the researcher, is a central concern (Madsen 2004). The school will obtain help and advice on developing its practice while the research is taking place, and the researcher is permitted to use the compiled data in her research as long as this data is within the agreed focus of the research.

In the CHAT paradigm one of the researcher's tasks is to develop practice during the research processes. The researcher will also write a text about how the classroom practice functions and develops, if indeed it does. At the subsequent stage the text may serve as a thinking tool for teachers in other classrooms who would like to change or develop their own practice. In traditional qualitative research conducted in the constructivist paradigm, research participants are invited to read the researcher's descriptions and analyses. Member-checking, which this procedure is called (Lincoln \& Guba 1985, Glesne \& Peshkin 1992, Miles \& Huberman 1994, Creswell 1998, Merriam 1998), is conducted to make the analyses in the text trustworthy. This procedure can be carried out both during the research process and after all the material has been collected and the analyses have been described in a complete text. Lincoln (1995) also proposes that researchers and research participants can share the privileges in the form of royalties from books or the sharing of rights to publication. If research participants want to be co-authors of texts using their real name, the principle of anonymity has to be reconsidered in the CHAT paradigm as in the constructivist paradigm. Again, it is the researcher's responsibility to protect the 
participants' privacy, and also the students' and their parents' privacy.

Sometimes it can be difficult to maintain anonymity because many people know about the ongoing research. Madsen (in progress) reflects on an experience during her study: "When I was doing fieldwork, I had to drive over the mountain. On the way down to the small villages on the other side, I can evidently be observed. When I get there, I have the feeling that everybody is sitting behind their curtains noting that I am here again to do research at their school. Once last autumn I was in the village shop. I had never done any shopping there before and I did not know the lady working there. I naively thought that she did not know me either. I bought a pear and a bar of chocolate. When paying I forgot the chocolate, took the pear with me and drove homewards. Five months later, in the spring, I again stopped at this shop and bought some fruit and chocolate. Just when I was going to pay, the lady gave me a chocolate saying: 'Didn't you forget this the last time you were here?" In small societies it is difficult not to be recognized. Everybody knows who the researcher is, but it does not necessarily mean that all the others taking part in the research processes need to be identified. In such a situation researchers and participants, as for instance teachers, can use fictive names to try to preserve the privacy of the participants, if they find it necessary.

\section{Concluding Comments}

In this text we have presented ethical codes that have been used both in the positivist and the constructivist paradigms. These codes were deception, avoidance of harm, privacy and confidentiality, informed consent, exploitation, anonymity and reciprocity. These codes have been outlined and discussed in connection with the two paradigms. The epistemological stance or the relation between researchers and the research participants is different in the positivist and constructivist paradigms. Nonetheless, the same codes are found useful. As we have seen, research in the CHAT paradigm is different from research in the constructivist paradigm both in purpose and process, although research in both these paradigms for the most part is qualitative. In this connection we have found that some ethical codes can be relevant, while some are non-issues, such as deception and exploitation. We have also found that some codes have to be introduced in the CHAT paradigm to fully embrace the research situations. While these codes will guide the various situations in which researchers and participants will take part, they will always be general and therefore have to be adapted to concrete situations. At the same time as these codes will direct researchers in their work, they also challenge their ability to be human beings in cooperating research situations. According to Smith (1990), caring, fairness, openness and truth seem to be important values underpinning the relationship and the activity of inquiry when researchers are working with people, as within the CHAT paradigm, rather than imposing actions. We would like to add that honesty, sensitivity, mutuality, trust and a willingness to share competence are ethical codes that can guide research in the CHAT paradigm. These codes also challenge the researchers' communicative, social and knowledge competence. Researchers have to have social competence to be sensitive to a person or an activity setting. If the research participants are to trust the researchers and really believe they can and are willing to contribute to the development of the studied practice, this knowledge has to be honestly and openly communicated.

\section{References}

Angrosino, M.V. \& Mays de Pérez, K.A. (2000). Rethinking Observation. From Method to Context. In N.K Denzin and Y.S. Lincoln (eds). 
Handbook of Qualitative Research, p. 673-702. Thousand Oaks: Sage Publications, Inc.

Bogden, R.C. \& Biklen, S.K. (1992). Qualitative Research for Education. An Introduction to Theory and Methods. Boston: Allyn and Bacon.

Creswell, J. W. (1998). Qualitative Inquiry and Research Design. Choosing Among Five Traditions. Thousand Oaks: Sage Publications, Inc.

Denzin, N.K. (1989). Interpretive Biography. Newbury Park, CA: Sage.

Diener, E. \& Crandall, R. (1978). Ethics in Social Behavioural Research. New York: The Guilford Press.

Engeström, Y. (1999). Activity Theory and Individual and Social Transformation. In Y. Engeström, R. Miettinen \& R. Punamaki (eds.). Perspectives on Activity Theory, p. 19-38. Cambridge, MA: Cambridge University Press.

Fetterman, D.M. (1998). Ethnography: Step by Step. Newbury Park, CA: Sage Publications, Inc.

Fontana, A. \& Frey, J.H. (1998). Interviewing: The Art of Science. In N.K. Denzin and Y.S. Lincoln (red.), Collecting and Interpreting Qualitative Materials, p. 47-78. Thousand Oaks: Sage Publications, Inc.

Fontana, A. \& Frey, J.H. (1994/2000). From Structured Questions to Negotiated Text. In N.K Denzin and Y.S. Lincoln (eds.). Handbook of Qualitative Research, p. 361-376, p. 645-672. Thousand Oaks: Sage Publications, Inc.

Glazer, M. (1982). The threat of the stranger: Vulnerability, reciprocity, and fieldwork. In J. Sieber (ed.). Ethics of Social Research: Fieldwork, Regulation, and Publication, p. 49-70. New York: Springer-Verlag.

Glesne, V. (1999). Becoming Qualitative Researchers. An Introduction. New York: Addison Wesley Longman, Inc.

Glesne, C. \& Peshkin, A. (1992). Becoming Qualitative Researchers. An Introduction. White Plains, N.Y.: Longman.

Guba, E.G. \& Lincoln, Y.S. (1989). Fourth Generation Evaluation. Newbury Park, CA: Sage Publications, Inc.

Habermas, J. (1993). Justification and Applica- tion: Remarks on Discourse Ethics (C. Cronin, Trans.). Cambridge: MIT Press.

Hammersley, M. \& Atkinson, P. (1995). Ethnography: Principles in Practice. London: Routledge.

Kvale, S. (1996). Interviews. An Introduction to Qualitative Research Interviewing. Thousand Oaks: Sage Publications, Inc.

Lincoln, Y.S. (1995). Emerging Criteria for Quality in Qualitative and Interpretative Research. Qualitative Inquiry, 1 (3), p. 275-289.

Lincoln, Y.S. \& Guba, E.G. (1985). Naturalistic Inquiry. Beverly Hills, CA: Sage Publications, Inc.

Madsen, J., Svendsen, G. og Gudmundsdottir, S. (2000). Kognitiv laretid. Undervisningsmetode som synliggjør laeringsprosessene og st $\phi t t e r$ elevene. [Cognitive apprenticeship. A teaching method that makes the learning processes visible and supports the pupils]. Trondheim: Tapir Akademiske Forlag [Publishing Firm].

Madsen, J. (2004). Sosiokulturell forskningstradisjon, aktivitetsteori og aksjonsforskning som gjensidige st $\varnothing$ ttespillere. [Sociocultural research tradition, activity theory and action research as mutual supporting theories]. In Tiller, T. (ed). Aksjonsforskning i skole og utdanning, [Action Research in schools and teaching], p. 143-162. Kristiansand. Høyskoleforlaget.

Madsen, J. (in progress). Lærerens læring i et skoleutviklingsprosjekt. [The teacher's learning during a school development project]. Preliminary title. Doctoral dissertation.

Merriam, S. (1998). Qualitative Research and Case Study Applications in Education. San Franscisco: Jossey-Bass Publishers.

Miles, M.B. \& Huberman, M.A. (1994). Qualitative Data Analysis. Thousand Oaks, CA: Sage Publications, Inc.

Moen, T. \& Gudmundsdottir, S. (1997). "Det å send han Tom ut av klassen, e ikkje nån lфysning”. En kasusstudie av inkluderende prosesser. ["Sending Tom out of Class Is Not a Good Option". A Case Study of Inclusion.] Trondheim: Tapir [Publishing firm].

Moustakas, C. (1994). Phenomenological Research Methods. Thousand Oaks: SAGE Publications.

Nilssen, V., Wangsmo-Cappelen, V. \& Gud- 
mundsdottir, S. (1996). "Dam taenkt på ein heil anna måte enn ka a gjor”. En kasusstudie av en larerstudents matematikkundervisning $i$ 2. klasse. [They thought in a completely different way than me. A case study of a teacher student's teaching in mathematics in the second grade] Trondheim: Tapir Akademisk Forlag [Publishing Form].

Pateman, C. (1989). The Disorder of Women: Democracy, Feminism and Political Theory. Stanford, CA: Stanford University Press.

Patton, M.Q. (2002). Qualitative Research \& Evaluation Methods. 3rd edition. Thousand Oaks: SAGE Publications.

Pettersson, T., "Tina", Flem, A. \& Gudmundsdottir, S. (2000). "Det levende ordet" $i$ en krevende klasse. ["The living word" in a demanding class.]. Tapir Akademisk Forlag. [Publishing Firm].

Postholm, M.B., Wold Granum, M. \& Gudmundsdottir, S. (1999). "Det her er vanskelig, altså”. En kasusstudie av prosjektarbeid. ["This Here is Pretty Difficult". A Case Study of Project Work]. Trondheim: Tapir. [Publishing firm].

Postholm, May Britt. (2003) "I can't find my grandma on the Internet". A Study of Project Work Using ICT as a Mediating Artefact. (Doctoral dissertation) NTNU, Trondheim: BIBSYS. http://www.ub.ntnu.no/doktoravhandlinger

Punch, M. (1994). The politics and ethics of fieldwork. Newbury Park, CA: Sage.

Reinertsen, A., Nordtømme, N.P., Eidsvik, R. Aa., Weideman, E. \& Gudmundsdottir, S. (1996). Fagdidaktisk kunnskap belyst gjennom undervisning $i$ hendelsene på Eidsvoll $i 1814$. [Pedagogical content knowledge illustrated by the teaching about the events at Eidsvoll in 1814]. Trondheim: Tapir Akademisk Forlag [Publishing Form].

Rommetveit, R. (1979). Deep Structure of Sentences Versus Message Structure. In R. Rommetveit \& R.M. Blakar (eds.), Studies of Language; Thought and Verbal Communication, p. 17-34. New York: Academic Press.

Root, M. (1993). Philosophy of Social Science: The Methods, Ideals, and Politics of Social Inquiry. Oxford: Blackwell.

Rubin, H.J. \& Rubin, I.S. (1995). Qualitative Interviewing. The Art of Hearing Data. Thousand Oaks: SAGE Publications.

Smith, L.M. (1990). The Ethics of Qualitative Research. In E.W. Eisner and A. Peshkin (eds.). Qualitative Inquiry in Education. The Continuing Debate, p. 247-257. New York: Teachers College Press.

Soltis, J.F. (1990). Ethics in Qualitative Field Research: An Individual Perspective. In E.W. Eisner and A. Peshkin (eds.). Qualitative Inquiry in Education. The Continuing Debate, p. 258-275. New York: Teachers College Press.

Stake, R.E. (1995). The Art of Case Study Research. Thousand Oaks, CA: Sage Publications, Inc.

Wardekker, W. (2000). Criteria for the Quality of Inquiry. In Mind, Culture, and Activity, 7, (4), p. 259-272.

Wertsch, J.V. (1984). The Zone of Proximal Development: Some Conceptual Issues. In B. Rogoff \& J.V. Wertsch (ed.). Children's Learning in the "Zone of Proximal Development". New Directions for Child Development, p. 7-18. San Francisco: Jossey-Bass. 